\title{
PENGEMBANGAN MEDIA PEMBELAJARAN POWER POINT MACRO BERBASIS PROBLEM BASED LEARNING MATERI BESARAN DAN PENGUKURAN SEBAGAI SUMBER BELAJAR SISWA KELAS $X$
}

\author{
Miswati ${ }^{1}$, Ahmad Amin ${ }^{2}$, Endang Lovisia ${ }^{3}$ \\ Miswati070598@gmail.com \\ 1,2,3 Program Studi Pendidikan Fisika STKIP PGRI Lubuklinggau, Sumatera Selatan, Indonesia
}

Received: 6 Oktober 2020

Revised: 30 November 2020

Accepted: 8 Desember 2020

\begin{abstract}
This study aims to "Develop Macro Power Point Learning Media Based on Problem Based Laerning on Quantity and Measurement Materials as Learning Resources for Class X Students". Problems in this study 1) How to develop problem-based learning media for power point learning on quantity and measurement material as a learning resource for class $X$ students ?,2) What are the characteristics of the learning media for power point macro based on problem based learning that has been developed to meet validity and practicality?, 3) How do students respond during learning using power point macro learning media based on problem based laerning ?. The development model used is Borg and Gall. There are 10 stages, namely: potential and problem stages, data collection, product design, design validation, design revision, product testing, product revision, usage testing, product revision and mass production. The research subjects of class X MIPA SMA AL-IKHLAS Lubuklinggau used purposive sampling technique. Data collection was carried out by means of observation, interview and questionnaire techniques. The validation was carried out to get results in a very good category with a score of 128. The instrumentation used to measure student responses was using a questionnaire. The student response was a limited group and the teacher got a score of 146 in the strongly agree category. The response of the main field testing group was by completing the 6 students' quiz questions based on KKM. For the student response questionnaire the main field testing group got a score of 312 in the strongly agree category. So it can be said that the learning media for power point macro based on problem based learning that has been developed are valid and practical.
\end{abstract}

\begin{abstract}
Abstrak: Penelitian ini bertujuan untuk "Mengembangkan Media Pembelajaran Power Point Macro Berbasis Problem Based Laerning pada Materi Besaran dan Pengukuran Sebagai Sumber Belajar Siswa Kelas X". Masalah dalam penelitian ini 1) Bagaimana cara mengembangkan media pembelajaran power point macro berbasis problem based laerning pada materi besaran dan pengukuran sebagai sumber belajar siswa kelas X?, 2) Bagaimanakah karakteristik media pembelajaran power point macro berbasis problem based laerning yang dikembangkan memenuhi sasaran kevalidan dan kepraktisan?, 3) Bagaimanakah respon siswa selama pembelajaran menggunakan media pembelajaran power point macro berbasis problem based laerning?. Model pengembangan yang digunakan yaitu Borg and Gall. Yang terdapat 10 tahapan yaitu: tahap potensi dan masalah, pengumpulan data, desain produk, validasi desain, revisi desain, uji coba produk, revisi produk, uji coba pemakaian, revisi produk dan produksi massal. Subjek penelitian kelas X MIPA SMA AL-IKHLAS Lubuklinggau dengan teknik purposive sampling. Pengumpulan data dilakukan dengan teknik observasi, wawancara, dan angket. Validasi yang dilakukan mendapatkan hasil dengan kategori sangat baik dengan skor 128. İnstrumentasi yang digunakan untuk menguku respon siswa menggunakan angket. Respon siswa kelompok terbatas dan guru mendapatkan skor 146 dalam kategori sangat setuju..Respon kelompok main field testing dengan mengerjakan soal quis 6 siswa tuntas berdasarkan KKM. Untuk angket respon siswa kelompok main field testing mendapatkan skor 312 dalam kategori sangat setuju. Sehingga dapat dikatakan bahwa media pembelajaran power point macro berbasis problem based laerning yang dikembangkan telah valid dan praktis.
\end{abstract}

Kata kunci $\quad$ : Power Point Macro, problem based laerning, Reseach and Development

Puplished at https://ojs.stkippgri-lubuklinggau.ac.id/index.php/SJPIF 


\section{PENDAHULUAN}

Pendidikan merupakan sesuatu hal yang penting dan mutlak yang merupakan kebutuhan pokok seseorang dalam kehidupan manusia untuk memenuhi kebutuhan dan tatanan hidup dalam rangka upaya peningkatan taraf hidup masyarakat. Dari pendidikan inilah diperoleh pengetahuan, keterampilan serta terwujudnya sikap dan tingkah laku dalam kehidupan seharihari (Amri dkk, 2010: 1). Pendidikan merupakan suatu proses yang diperlukan untuk mendapatkan keseimbangan dan kesempurnaan dalam perkembangan individu maupun masyarakat. Penekanan pendidikan dibanding dengan pengajaran terletak pada pembentukan kesadaran dan kepribadian individu atau masyarakat di samping transfer ilmu dan keahlian (Zakiya, Z., Amin, A., \& Lovisia, E, 2019). Pendidikan yang di kelola dengan tertib, teratur, efektif, dan efisien (berdaya guna) yang dapat mempercepat jalannya usaha pembudayaan bangsa yang berdasarkan pada pokok menciptakan kesejahteraan umum dan mencerdaskan kehidupan bangsa kita ini sesuai dengan tujuan nasional yang telah tercantum dalam alenia ke-IV, dalam pembukaan UUD 1945.

Berdasarkan wawancara yang telah dilakukan di kelas X SMA AL-IKHLAS Lubuklinggau masalah yang sering dihadapi dalam mata pelajaran fisika adalah kurangnya motivasi peserta didik dalam proses pembelajaran. Hal ini mengakibatkan hasil belajar peserta didik menjadi rendah. Proses pembelajaran fisika selalu identik dengan pembelajaran konvensional dimana guru lebih berperan aktif dalam menyampaikan konsep materi fisika, sedangkan peserta didik tidak tahu bagaimana proses penemuan konsep materi fisika tersebut. Selain itu, banyak siswa yang menganggap materi fisika ini dikatakan materi yang sangat rumit untuk dipelajari. Pembelajaran fisika merupakan proses antara guru dan siswa yang melibatkan pengembangan pola berpikir dan mengola logika pada suatu lingkungan belajar yang sengaja diciptakan oleh guru dengan berbagai metode agar program belajar fisika tumbuh dan berkembang secara optimal dan siswa dapat melakukan kegiatan belajar secara efektif dan efesien. Pembelajaran fisika yang diberikan tidak hanya transfer pengetahuan tetapi sesuatu yang harus dipahami oleh peserta didik yang diperlukan dalam kehidupan sehari-hari (Uskarina, M, 2019). Proses kegiatan belajar mengajar fisika kerap sekali dihadapkan pada sebuah materi yang abstrak. Pelajaran fisika masih terkesan sulit untuk dipahami karena memiliki konsep yang abstrak dan tidak mudah dihubungkan dengan kejadian sehari-hari dalam kehidupan manusia. Hal ini menuntut para pendidik untuk kreatif dalam menciptakan dan mengembangkan media-media pembelajaran agar siswa dapat lebih 
tertarik dalam mempelajari fisika dan materi yang disampaikan dapat benar-benar dimengerti oleh peserta didik (Maryam, E., \& Fahrudin, A, 2020).

Dalam kegiatan belajar mengajar pada saat observasi berlangsung di Kelas X MIPA guru telah menggunakan media proyektor seperti power point, namun media yang digunakan oleh guru masih bersifat biasa, seperti materi, contoh soal beserta rumus-rumus yang terdapat di dalam power point masih bersifat terpisah, artinya tidak seluruh materi ada di dalam power point sehingga ketika guru menjelaskan harus membuka tampilan materi dalam bentuk word. Selain itu, di dalam power point guru telah memasukkan video animasi yang berhubungan dengan materi, namun video tersebut tidak dapat ditampikan di dalam power point karena guru tidak bisa memasukkan video di dalam power point tersebut, serta tampilan yang masih bersifat biasa yang masih belum sepenuhnya dapat membuat siswa tertarik untuk belajar.

Mengenai permasalahan diatas, peneliti ingin menggagas alternatif baru dalam mempelajari materi pelajaran fisika yang dapat membantu meningkatkan motivasi belajar siswa. Salah satu pengembangan yang popular saat ini adalah media pembelajaran power point macro berbasis problem based learning, yang dimana media ini tidak banyak diketahui oleh pendidik yang ada dikawasan lubuklinggau. Pendidik hanya tahu dengan media proyektor yang berupa power point biasa yang sering digunakan oleh pendidik dalam proses pembelajaran. Disini peneliti ingin mencoba memperbaiki mutu pendidikan siswa dengan menggunakan media pembelajaran dari multimedia projector atau lebih dikenal dengan LCD proyektor yang berupa media pembelajaran power point macro dimana didalamnya tidak hanya terdapat point-point penting dari materi saja akan tetapi akan ada juga soal-soal latihan dan soal-soal kuis dari pembahasan materi serta video animasi yang ditampilkan menjadi satu kesatuan di dalam power point macro tersebut, sehingga nantinya power point macro ini dapat menarik perhatian, semangat serta dapat memotivasi siswa untuk belajar, sehingga siswa tidak merasa jenuh dan bosan lagi dalam proses pembelajaran.

Dengan situasi, kondisi dan kenyataan yang ada mengenai permasalahan yang terjadi disekolah, khususnya di SMA AL-IKHLAS Lubuklinggau yang peneliti gunakan dalam penelitian ini, maka peneliti tertarik untuk menarik judul "Pengembangan Media Pembelajaran Power Point Macro Berbasis Problem Based Learning Materi Besaran dan Pengukuran Sebagai Sumber Belajar Siswa Kelas X". Tujuan penelitian yang ingin dicapai oleh peneliti ini adalah: (1) Untuk mengetahui cara mengembangkan media pembelajaran power point macro berbasis problem based learning pada materi besaran dan pengukuran sebagai sumber belajar siswa kelas X. (2) Untuk mengetahui karakteristik media 
pembelajaran power point macro berbasis problem based learning pada materi besaran dan pengukuran sebagai sumber belajar siswa kelas $\mathrm{X}$ yang dikembangkan memenuhi sasaran kevalidan dan kepraktisan. (3) Untuk mengetahui respon siswa selama pembelajaran menggunakan media pembelajaran power point macro berbasis problem based learning pada materi besaran dan pengukuran sebagai sumber belajar siswa kelas $\mathrm{X}$ yang dikembangkan dalam penelitian ini.

\section{METODOLOGI PENELITIAN}

Metode yang digunakan dalam penelitian yaitu Research and Development ( $R \& D)$. Dalam penelitian ini peneliti mengembangkan sebuah media pembelajaran power point macro berbasis problem based learning pada materi besaran dan pengukuran. Model pengembangan yang digunakan yaitu Borg and Gall. Yang terdapat 10 tahapan yaitu: tahap potensi dan masalah, pengumpulan data, desain produk, validasi desain, revisi desain, uji coba produk, revisi produk, uji coba pemakaian, revisi produk dan produksi massal. Namun dalam penelitian ini peneliti hanya menggunakan 8 tahap saja. Hal itu dikarenakan sistem belajar bersifat daring akibat mewabahnya virus covid-19. Serta keterbatasan biaya dan waktu yang tidak efektif. Adapun kesepuluh langkah tersebut dapat digambarkan dalam gambar 1 .

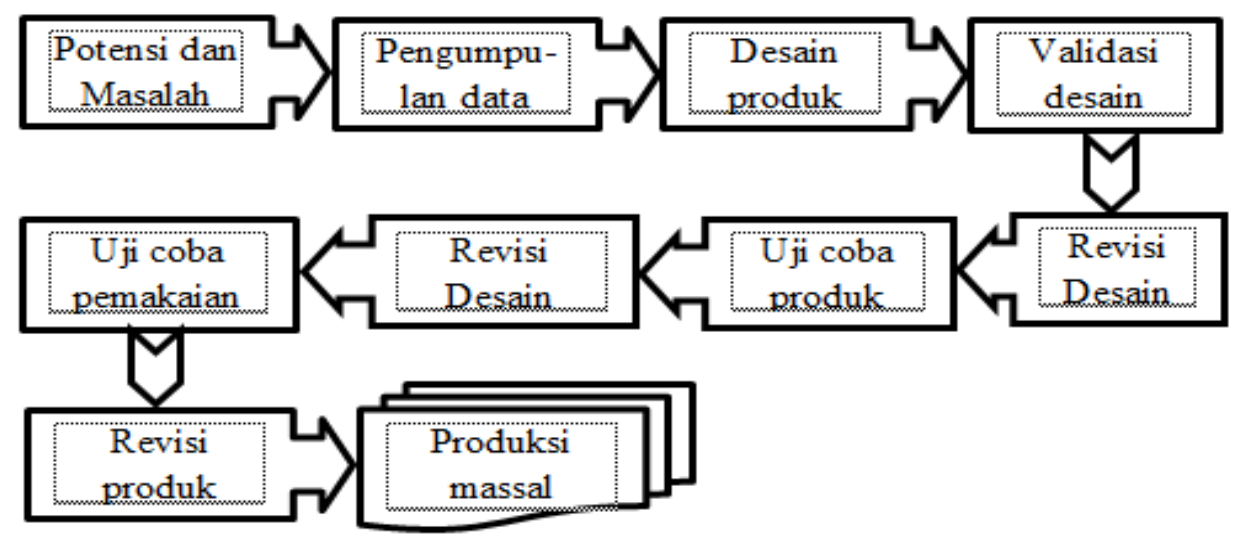

Gambar 1. Langkah-langkah penggunaan Model Pengembangan Borg and Gall (dalam Sugiyono, 2007)

Teknik pengumpulan data dalam penelitian ini menggunakan observasi, wawancara, dan angket. Adapun instrumen yang digunakan untuk melihat kelayakan dari media pembelajaran power point macro berbasis problem based learning yang dikembangkan yaitu menggunakan angket kevalidan, dan angket kepraktisan. Teknik pengambilan sampel yang digunakan dalam penelitian ini yaitu purposive sampling dimana peneliti menggunakan kelas penelitian 
berdasarkan pertimbangan. Peneliti melakukan 2 tahap pengujian yaitu dengan menggunakan uji kelompok terbatas dan main field testing. Pada uji kelompok terbatas peneliti menggunakan lembar respon siswa dengan 3 orang siswa kelas X MIPA SMA AL-IKHLAS Lubuklinggau, kemudian memberikan angket dengan 9 orang siswa kelas X MIPA SMA AL-IKHLAS Lubuklinggau. Angket ini berisi 10 pernyataan yang harus diberikan tanggapan oleh siswa dan guru. Untuk menghitung skor angket menggunakan rumus:

Tabel 1. Rentang Skor Masing-masing Angket Validasi dan Angket Respon Siswa

\begin{tabular}{ccll}
\hline No & \multicolumn{1}{c}{ Rentang skor (i) } & Nilai & \multicolumn{1}{c}{ Kategori } \\
& & & \\
\hline 1 & $\mathrm{X}>\bar{x}+1,80 \mathrm{Sb} i$ & $\mathrm{~A}$ & Sangat baik \\
2 & $\bar{x}+0,60 \mathrm{SB} i<\mathrm{X} \leq \overline{\mathrm{x}}+1,80 \mathrm{SB} i$ & $\mathrm{~B}$ & Baik \\
3 & $\bar{x}-0,60 \mathrm{SB} i<\mathrm{X} \leq \overline{\mathrm{x}}+0,60 \mathrm{SB} i$ & $\mathrm{C}$ & Cukup baik \\
4 & $\bar{x}-1,80 \mathrm{SB} i<\mathrm{X} \leq \overline{\mathrm{x}}-0,60 \mathrm{SB} i$ & $\mathrm{D}$ & Kurang baik \\
5 & $\mathrm{X} \leq \overline{\mathrm{x}}-1,80 \mathrm{SB} i$ & $\mathrm{E}$ & $\begin{array}{l}\text { Sangat kurang } \\
\text { baik }\end{array}$ \\
\hline
\end{tabular}

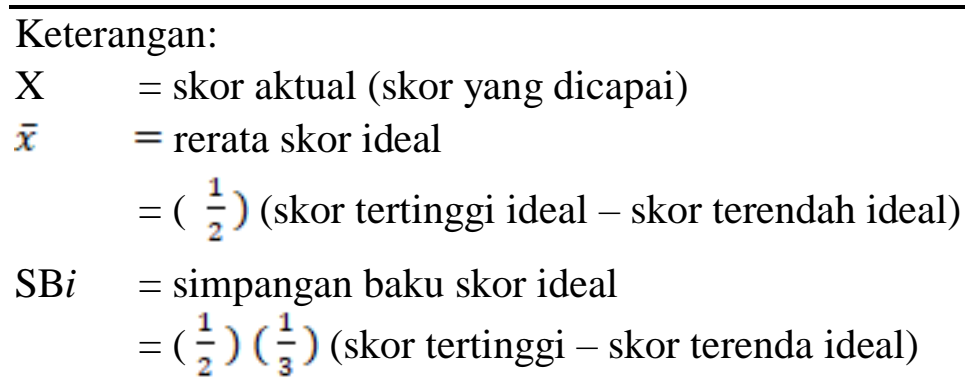

Skor tertinggi ideal $=\sum$ butir kriteria $\mathrm{x}$ skor tertinggi

Skor terendah ideal $=\sum$ butir kriteria $\mathrm{x}$ skor terendah

\section{HASIL DAN PEMBAHASAN}

Kelayakan media pembelajaran power point macro berbasis problem based learning secara teoritik melalui tahapan evaluasi ahli untuk melihat kevalidan media pembelajaran power point macro yang di validasi oleh para ahli. Evaluasi ahli dilakukan untuk menyempurnakan media pembelajaran power point macro yang dikembangkan dari segi materi, media, dan bahasa. Berdasarkan penilaian dari keempat orang ahli terhadap media pembelajaran power point macro berbasis problem based learning yang sudah diuraikan di atas menunjukkan penilaian yang sangat baik. Oleh karena itu, media pembelajaran power point macro berbasis problem based learning dapat dikatakan valid dan dapat digunakan untuk tahap selanjutnya yaitu tahap uji coba yang akan dilaksanakan di SMA AL-IKHLAS Lubuklinggau. Media pembelajaran power point macro yang dikembangkan melewati 
beberapa tahapan untuk mendapatkan media pembelajaran power point macro final atau media pembelajaran power point macro yang digunakan untuk penelitian. Tahapan tersebut seperti yang dijelaskan di bawah ini

\section{a. Power Point Macro Draf I}

Pada media pembelajaran power point macro draf 1, peneliti telah merancang media pembelajaran power point macro berbasis problem based learning dengan materi besaran dan pengukuran yang belum divalidasi dan belum dinilai. Berikut media pembelajaran power point macro draf 1 pada gambarpada gambar 2 .

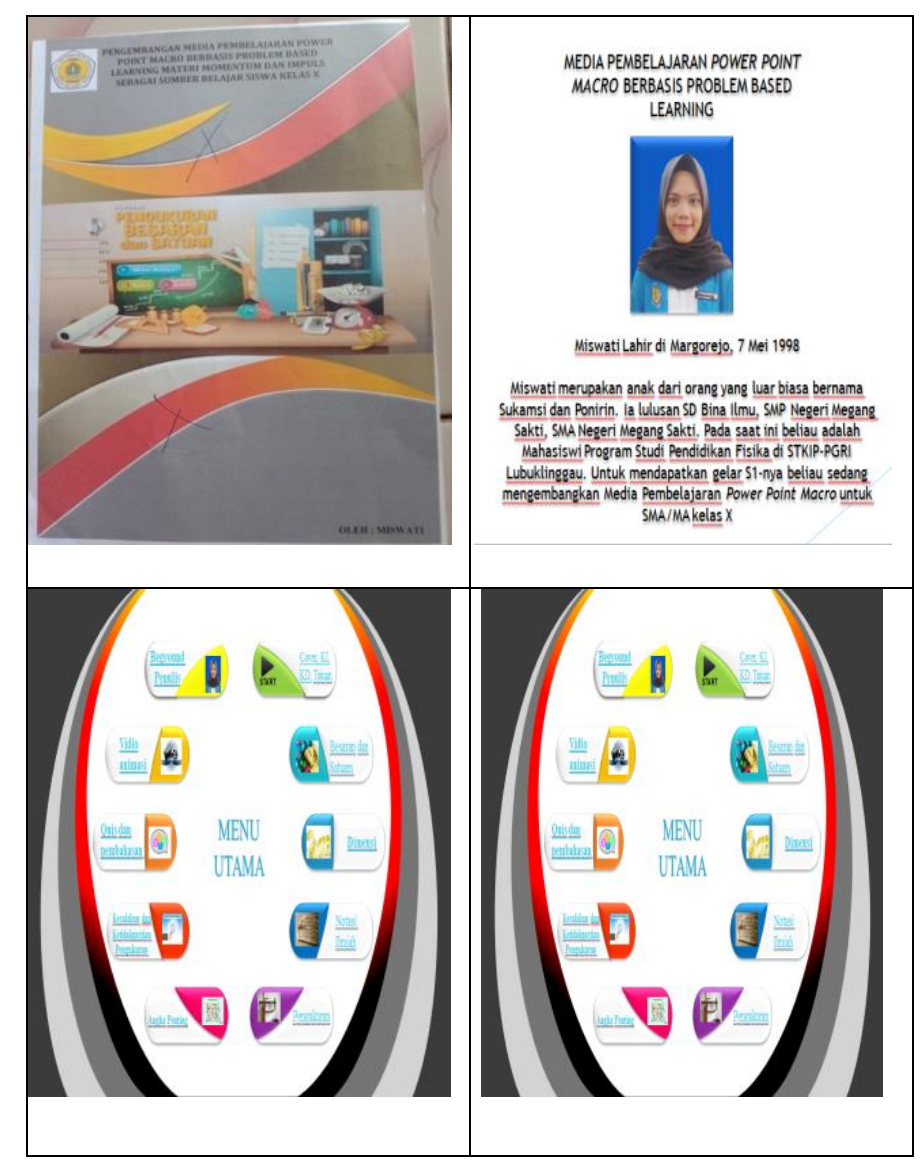

Gambar 2. Draf Media Pembelajaran Power Point Macro 1

Setelah media pembelajaran power point macro draf 1 selesai dirancang, selanjutnya peneliti memberikan media pembelajaran power point macro untuk divalidasi oleh ahli materi, media dan bahasa untuk memberikan penilaian dan perbaikan terhadap media pembelajaran power point macro yang dirancang.

\section{b. Power Point Macro Draf II}

Pada media pembelajaran power point macro draf 2 ini merupakan perbaikan dari media pembelajaran power point macro draf 1 sebelumnya. Media pembelajaran power point macro Puplished at https://ojs.stkippgri-lubuklinggau.ac.id/index.php/SJPIF 
dinilai dan diperbaiki melalui validator ahli, dosen fisika, dan guru fisika, yang mana para validator meminta untuk memperbaiki tampilan desain menu dan cover untuk diperbaiki agar terlihat selaras dengan materi. Selanjutnya penulis melakukan beberapa hal yang harus diperbaiki sebelum melakukan penelitian. Berikut perbaikan setelah divalidasi sesuai saran dan masukan pada gambar 3.

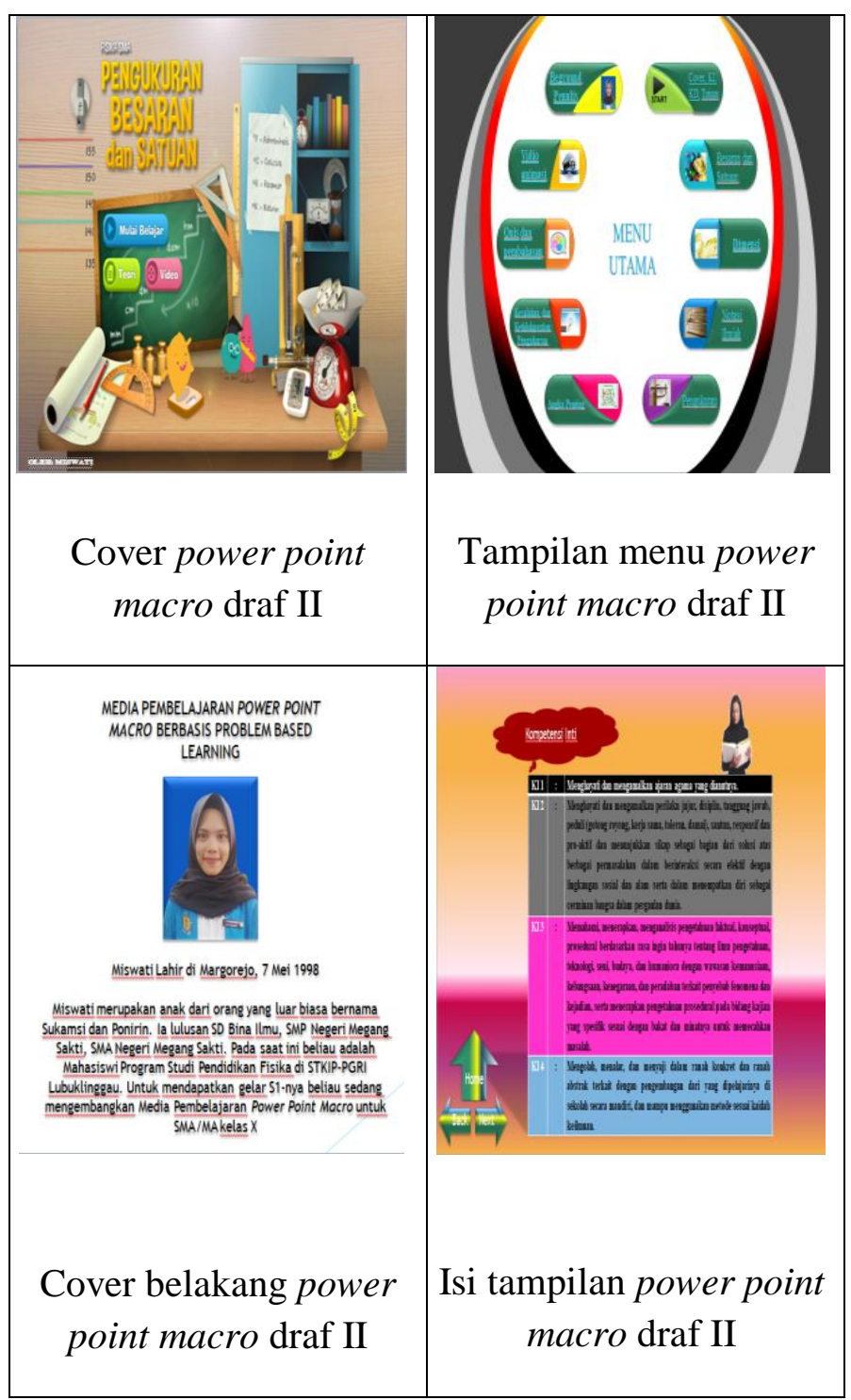

Gambar 3. Draf power point macro II

Setelah power point macro draf 2 selesai dirancang, selanjutnya peneliti memberikan power point macro untuk divalidasi oleh ahli materi dan media untuk memberikan saran dan masukan terhadap power point macro yang dirancang.

\section{c. Power Point Macro Final}

Media pembelajaran power point macro berbasis problem based learning pada materi besaran dan pengukuran berdasarkan draf 1 dan draf 2 yang telah dinilai dan diperbaiki oleh 
validator, maka selanjutnya media pembelajaran power point macro setelah tahapan draf 1 dan draf 2 media pembelajaran power point macro ini bisa dipakai saat melakukan uji coba kelompok terbatas dan uji coba main field testing untuk melihat respon siswa mengenai media pembelajaran power point macro sebelum media pembelajaran power point macro tersebut digunakan langsung dikelas pada saat penelitian.

Setelah melewati beberapa tahapan uji coba tersebut akhirnya didapat media pembelajaran power point macro pada tahap final tanpa melakukan revisi kemudian dapat digunakan oleh peneliti dalam melakukan suatu penelitian di SMA AL-IKHLAS Lubuklinggau pada kelas X MIPA yang akan diterapkan media pembelajaran power point macro berbasis problem based learning.

Desain cover dan isi dari media pembelajaran power point macro yang dikembangkan dapat dilihat pada gambar 4 .

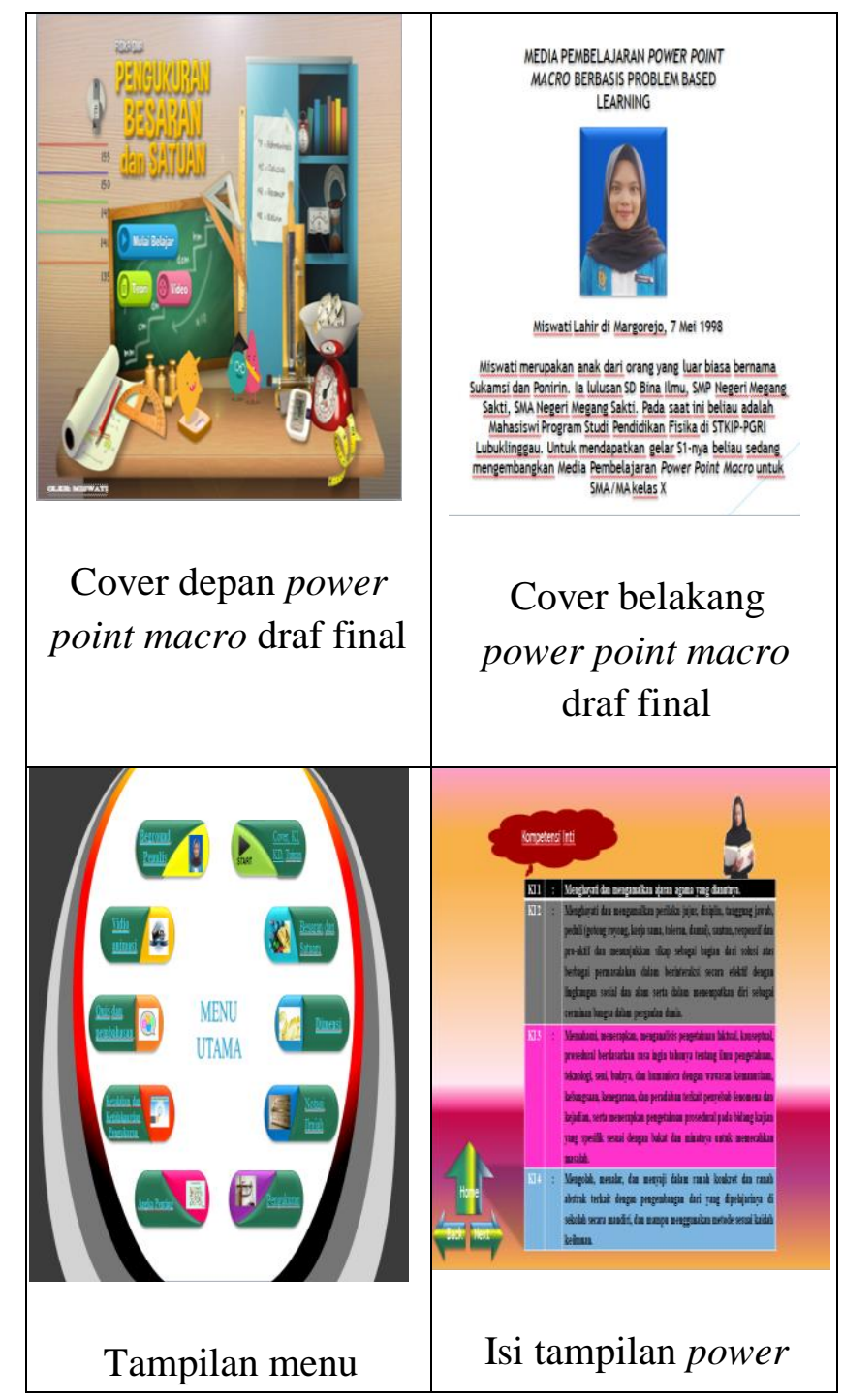

Puplished at https://ojs.stkippgri-lubuklinggau.ac.id/index.php/SJPIF 


\begin{tabular}{|c|c|}
\hline $\begin{array}{c}\text { power point macro } \\
\text { draf final }\end{array}$ & point macro draf final \\
\hline
\end{tabular}

Gambar 4. Draf power point macro Final

\section{KELAYAKAN MEDIA PEMBELAJARAN POWER POINT MACRO}

Kelayakan dari media pembelajaran power point macro berbasis problem based learning ini dilihat dari hasil validasi yang dilakukan kepada beberapa ahli dan dari beberapa aspek. Evaluasi ahli dilakukan untuk menyempurnakan media pembelajaran power point macro yang dikembangkan dari segi materi, media, dan bahasa. Sebagai ahli materi dipilih seorang dosen prodi Fisika dan sebagai tambahan guru fisika. Sebagai ahli media dipilih dosen prodi matematika. Sedangkan sebagai ahli bahasa dipilih seorang dosen prodi bahasa Indonesia. Keempat validator ini dipilih melalui rekomendasi dari pihak LP4MK STKIP-PGRI Lubuklinggau untuk memberikan penilaian dan saran terhadap media pembelajaran power point macro yang peneliti kembangkan. Sedangkan guru sekolah dipilih oleh peneliti. Instrumen yang digunakan adalah angket terbuka, berdasarkan indikator dan saran yang dibutuhkan dalam mengembangkan media pembelajaran power point macro berbasis problem based learning. Secara rinci peneliti uraikan sebagai berikut.

Validasi materi yang dilakukan kepada dosen Fisika sebanyak dua kali. Hal ini dimaksudkan untuk memaksimalkan dan agar materi dalam media pembelajaran power point macro yang dikembangkan semakin baik. Hasil tanggapan ahli pada validasi komponen materi yang pertama mendapatkan skor 36. Dari hasil analisis validasi yang pertama ini termasuk dalam kategori sangat baik.

Validasi materi selanjutnya dilakukan kepada salah satu validator ahli materi yaitu kepada guru Fisika SMA AL-IKHLAS Lubuklinggau. Validasi materi yang dilakukan kepada guru fisika disekolah hanya dilakukan sekali tanpa revisi. Hal itu dikarenakan sebelumnya media pembelajaran power point macro ini telah divalidasi oleh dosen fisika. Validasi yang dilakukan oleh guru fisika ini mendapatkan skor 46. Dari hasil analisis validasi ini termasuk dalam kategori sangat baik. Artinya media pembelajaran power point macro yang dikembangkan layak digunakan dari segi materi.

Validasi Kedua adalah hasil dari validasi tata bahasa. Validasi tata bahasa dilakukan kepada ahli bahasa yaitu dosen bahasa indonesia. Validasi yang dilakukan dari segi tata bahasa ini dilaksanakan dua kali. Hasil tanggapan dari validasi komponen tata bahasa mendapatkan skor 18. Dari hasil analisis validasi ini termasuk dalam kategori baik. 
Validasi ketiga adalah hasil dari validasi media atau desain. Validasi media atau desain dilakukan kepada ahli media atau desain yaitu salah satu dosen matematika yang menjadi ahli media di STKIP-PGRI Lubuklinggau. Hasil tanggapan dari validasi media mendapatkan skor 28. Dari hasil analisis validasi ini termasuk dalam kategori baik dan media pembelajaran power point macro yang dikembangkan layak untuk digunakan dari segi media.

Berdasarkan hasil penilaian tahap validasi oleh para ahli yang telah dilakukan terhadap media pembelajaran power point macro berbasis problem based learning yang telah diuraikan di atas menunjukkan maka kevalidan media pembelajaran power point macro yang dikembangkan mendapatkan skor keseluruhan yaitu 128 yang termasuk dalam kategori sangat baik sehingga media pembelajaran power point macro yang dikembangkan layak untuk digunakan dalam kegiatan belajar mengajar dengan tetap melakukan perbaikan sesuai dengan saran dan komentar yang diberikan dan media pembelajaran power point macro berbasis problem based learning dapat digunakan untuk tahap selanjutnya yaitu uji coba yang akan dilaksanakan di SMA AL-IKHLAS Lubuklinggau. Hasil validasi yang telah dilaksanakan oleh ketiga ahli dapat dilihat pada tabel 2.

Tabel 2. Rekapitulasi Tanggapan Keempat Ahli

\begin{tabular}{|c|c|c|c|}
\hline No. & Validator & $\begin{array}{c}\text { Hasil } \\
\text { Penilaian }\end{array}$ & Kategori \\
\hline 1 & $\begin{array}{l}\text { Validasi Materi Dosen } \\
\text { Fisika }\end{array}$ & 36 & Sangat Baik \\
\hline 2 & $\begin{array}{l}\text { Validasi Materi Guru } \\
\text { Fisika }\end{array}$ & 46 & Sangat Baik \\
\hline 3 & Validasi Media & 28 & Baik \\
\hline 4 & $\begin{array}{l}\text { Validasi Tata Bahasa } \\
\text { Total }\end{array}$ & $\begin{array}{c}18 \\
128\end{array}$ & $\begin{array}{c}\text { Baik } \\
\text { Sangat Baik }\end{array}$ \\
\hline
\end{tabular}

\section{KEPRAKTISAN MEDIA PEMBELAJARAN POWER POINT MACRO}

Kepraktisan media pembelajaran power point macro berbasis problem based learning di ujikan dengan melewati beberapa uji coba. Uji coba yang dilakukan adalah uji coba kelompok terbatas dan uji coba main field testing untuk melihat kepraktisan dari media pembelajaran power point macro yang dilaksanakan di SMA AL-IKHLAS Lubuklinggau. Setiap uji coba dilakukan dengan mengunakan subjek penelitian yang berbeda.

Uji coba kelompok terbatas dilaksanakan pada senin, 25 Juli 2020 dengan 3 orang siswa berkemampuan tinggi, sedang, dan rendah. Uji coba kelompok terbatas dilakukan didalam kelas X MIPA, namun masih bersifat daring. Hal ini dikarenakan sistem pembelajaran masih 
bersifat daring akibat mewabahnya virus covid-19. Selain siswa, gurupun juga ikut mengisi angket guna melihat respon guru terhadap media pembelajaran power point macro. Angket yang digunakan bersifat terbuka yang terdiri dari 10 butir pernyataan, dengan angket terbuka ini setiap responden dapat memberikan saran dan komentar terhadap media pembelajaran power point macro yang peneliti kembangkan. Namun, untuk angket guru yang dilakukan oleh guru fisika tidak terdapat saran dan komentar apapun, itu artinya media pembelajaran power point macro yang peneliti kembangkan sudah layak digunakan dan bersifat praktis.

Hasil respon siswa dan guru pada uji coba kelompok terbatas dsisajikan dalam bentuk diagram dapat dilihat pada gambar 5 .

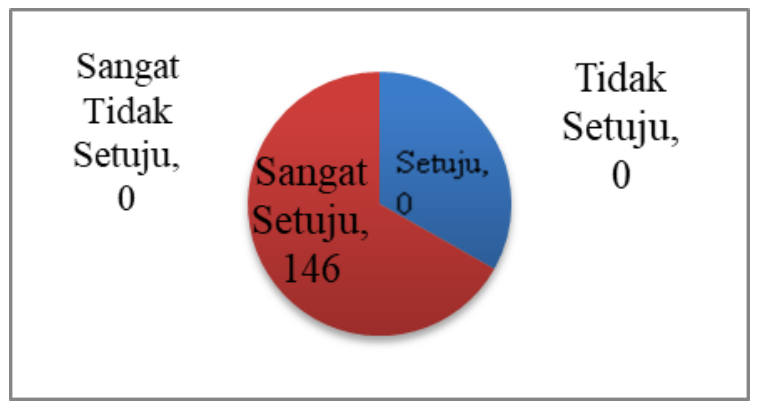

Gambar 5. Diagram hasil respon siswa uji coba kelompok terbatas

Tabel 3. Hasil Penilaian Angket Kepraktisan Kelompok Terbatas

\begin{tabular}{|c|c|c|c|}
\hline No. & Subjek & Hasil penilaian & Ketegori \\
\hline 1 & $\begin{array}{c}\text { Siswa berkemampuan } \\
\text { tinggi }\end{array}$ & 37 & Sangat Setuju \\
\hline 2 & $\begin{array}{c}\text { Siswa berkemampuan } \\
\text { sedang }\end{array}$ & 38 & Sangat Setuju \\
\hline 3 & $\begin{array}{l}\text { Siswa berkemampuan } \\
\text { rendah }\end{array}$ & 33 & Sangat Setuju \\
\hline 4 & $\begin{array}{l}\text { Guru Fisika } \\
\text { Total }\end{array}$ & $\begin{array}{r}38 \\
146\end{array}$ & $\begin{array}{l}\text { Sangat Setuju } \\
\text { Sangat Setuju }\end{array}$ \\
\hline
\end{tabular}

Uji coba main field testing dilaksanakan pada hari senin 30 juli 2020 dengan 9 orang siswa yang terdiri dari 3 orang siswa berkemampuan tinggi, 3 orang siswa berkemampuan sedang, dan 3 orang siswa berkemampuan rendah. Uji coba main field testing dilakukan di ruang kelas X MIA, namun masih melalui daring. Hal ini dikarenakan sistem pembelajaran masih bersifat daring akibat mewabahnya virus covid-19. Pada saat uji coba main field testing dilaksanakan yang dilakukan oleh peneliti untuk mendapatkan respon siswa menggunakan angket. Dari angket respon siswa yang telah diberikan oleh 9 orang siswa semuanya memberikan komentar yang positif secara analisis deskriptif. Untuk pengerjaan soal quis dari 
9 siswa yang mengerjakan $60 \%$ siswa yang tuntas berdasarkan KKM. İtu artinya media pembelajaran power point macro dalam kategori praktis.

Hasil sikap siswa pada uji coba main field testing disajikan dalam bentuk diagram dapat dilihat pada gambar 6 .

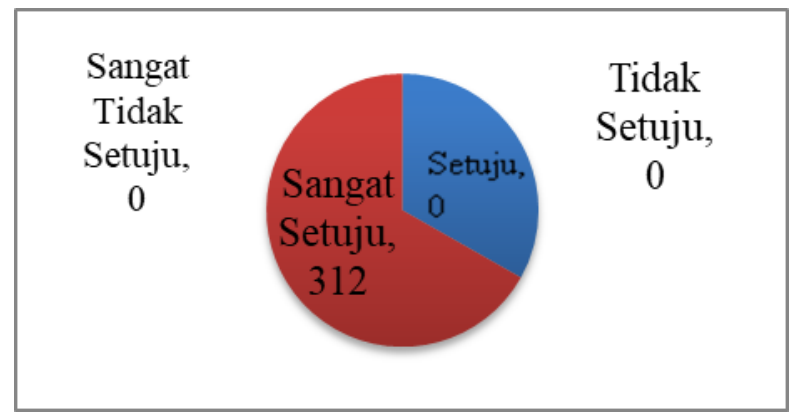

Gambar 6. Diagram hasil respon siswa uji coba main field testing

Tabel 4. Hasil Penilaian Angket Respon Main Field Testing

\begin{tabular}{cccc}
\hline No. & Subjek & Hasil penilaian & Ketegori \\
\hline 1 & $\begin{array}{c}\text { Siswa berkemampuan } \\
\text { tinggi }\end{array}$ & 37 & Sangat Setuju \\
2 & $\begin{array}{c}\text { Siswa berkemampuan } \\
\text { tinggi }\end{array}$ & 40 & Sangat Setuju \\
3 & $\begin{array}{c}\text { Siswa berkemampuan } \\
\text { tinggi }\end{array}$ & 34 & Sangat Setuju \\
4 & $\begin{array}{c}\text { Siswa berkemampuan } \\
\text { sedang }\end{array}$ & 38 & Sangat Setuju \\
5 & $\begin{array}{c}\text { Siswa berkemampuan } \\
\text { sedang }\end{array}$ & 32 & Sangat Setuju \\
6 & $\begin{array}{c}\text { Siswa berkemampuan } \\
\text { sedang }\end{array}$ & 32 & Sangat Setuju \\
7 & $\begin{array}{c}\text { Siswa berkemampuan } \\
\text { rendah }\end{array}$ & 31 & Sangat Setuju \\
8 & $\begin{array}{c}\text { Siswa berkemampuan } \\
\text { rendah }\end{array}$ & 32 & Sangat Setuju \\
9 & Siswa berkemampuan \\
rendah & 36 & Sangat Setuju \\
& Total & 312 & Sangat Setuju \\
\hline
\end{tabular}

Hal ini sejalan dengan pendapat dari Tanjung, dkk (2018) diperoleh hasil penelitian dari nilai $\mathrm{N}$-gain rata-rata keterampilan pemecahan masalah siswa yang diterapkan pembelajaran konvensional pada materi Momentum dan Impuls di kelas X semester II SMAN 13 Medan T.P. 2017/2018 yaitu 63\% (sedang). Berdasarkan uji t diperoleh bahwa $5.676>1.671$ yang berarti ada pengaruh yang signifikan model PBL berbantuan simulasi computer terhadap keterampilan pemecahan masalah siswa pada materi Momentum dan Impuls di kelas X SMAN 13 Medan T.P. 2017/2018. N-gain rata-rata keterampilan 
pemecahan masalah siswa yang diterapkan PBL berbantuan simulasi computer pada materi pokok Momentum dan Impuls di kelas X SMAN 13 Medan T.P. 2017/2018 yaitu 76\% (tinggi). Sehingga dapat disimpulkan analisis uji t diperoleh ada perbedaan yang signifikan akibat pengaruh model PBL terhadap keterampilan pemecahan masalah siswa pada materi momentum dan impuls.

Pendapat serupa juga dikemukakan oleh Zulhaini, dkk (2016) dalam penelitiannya yang berjudul pengembangan modul fisika kontekstual hukum newton untuk meningkatkan pemahaman konsep fisika siswa di MAN Model Banda Aceh mendapatkan hasil bahwa modul yang dikembangkan telah valid, praktis, dan efektif serta berkualitas untuk digunakan pada proses belajar mengajar. Modul yang dikembangkan tersebut dapat diterima dengan baik oleh peserta didik, hal tersebut terlihat dari hasil respon peserta didik yang baik. Serta hasil uji coba yang menunjukkan setelah penggunaan modul yang dikembangkan tersebut mengalami peningkatan dari 54,84\% menjadi $81,80 \%$ yang berada pada kualifikasi sangat baik. Maka dapat dikaitkan bahwa antara penelitian yang dilakukan dengan hasil penelitian yang dilakukan oleh Zulhaini, dkk mendapatkan hasil bahwa buku ajar fisika berbasis Contextual Teaching and Learning (CTL) baik digunakan pada proses pembelajaran serta dapat meningkatkan hasil belajar kognitif peserta didik.

\section{KESIMPULAN DAN SARAN}

\section{A. KESIMPULAN}

Berdasarkan penelitian yang telah dilakukan, peneliti menyimpulkan bahwa:

1. Peneliti melakukan pengembangan media pembelajaran power point macro berbasis problem based learning pada materi besaran dan pengukuran. Peneliti mengembangkan media pembelajaran power point macro berbasis problem based learning dengan cara menggunakan model penelitian dan pengembangan Borg and Gall melalui 10 tahapan. Namun peneliti hanya menggunakan 8 tahapan saja mengingat waktu dan biaya yang kurang efektif serta sistem pembelajaran yang bersifat daring akibat mewabahnya virus covid-19. Tahapan model pengembangan Borg and Gall yaitu analisis kebutuhan, perencanaan, pengembangan draft produk, uji coba ke-1, revisi ke-1, uji coba ke-2, revisi ke-2, uji coba ke-3, revisi ke-3, dan diseminasi atau publikasi.

2. Karakteristik media pembelajaran power point macro berbasis problem based learning yang dikembangkan dapat terlihat dari tingkat kevalidan dan kepraktisan. Dimana kevalidan terlihat dari hasil penilaian validator terhadap kualitas media pembelajaran 
power point macro berbasis problem based learning pada komponen kelayakan tata bahasa, kelayakan materi dosen fisika dan guru fisika serta kelayakan media. Dimana skor keseluruhan komponen tersebut adalah 128 sehingga media pembelajaran power point macro berbasis problem based learning pada materi besaran dan pengukuran dikatakan telah valid dengan kategori sangat baik.

3. Untuk kepraktisan dapat terlihat melalui respon uji coba kelompok terbatas dan uji coba main field testing dimana kelompok main field testing juga mengerjakan soal quis yang memperoleh skor keseluruhan 146, sehingga media pembelajaran power point macro berbasis problem based learning pada materi besaran dan pengukuran dikatakan telah praktis dengan kategori sangat baik. Oleh sebab itu, media pembelajaran power point macro berbasis problem based learning pada materi besaran dan pengukuran tahun pelajaran 2020/2021 dapat dikatakan valid dan praktis.

\section{B. SARAN}

Adapun saran pemanfaatan dan pengembangan produk lebih lanjut adalah sebagai berikut:

1. Penulis menyarankan agar media pembelajaran power point macro berbasis problem based learning dapat digunakan dalam pembelajaran materi besaran dan pengukuran karena telah mendapatkan nilai penilaian sangat baik dan layak digunakan.

2. Penulis menyarankan agar guru dapat mengelola media pembelajaran power point macro berbasis problem based learning pada materi besaran dan pengukuran yang dapat membantu guru dalam menyampaikan suatu materi.

3. Media pembelajaran power point macro berbasis problem based learning dapat dikolaborasikan dengan model pembelajaran yang lain selama masih menyertakan komponen problem based learning.

\section{DAFTAR PUSTAKA}

Amri, S. \& Ahmadi, I. K. (2010). Konstruksi Pengembangan Pembelajaran: Pengaruhnya Terhadap Mekanisme dan Praktik Kurikulum. Jakarta: Prestasi Pustaka.

Al-Tabany, T. I. B. (2014). Mendesain Model Pembelajaran Inovatif, Progresif, dan Kontekstual: Landasan, dan Implementasinya pada Kurikulum 2013 (Kurikulum Tematik Integratif/TKI). Jakarta: Kencana.

Daryanto. (2014). Media Pembelajaran: Peranannya Sangat Penting Dalam Mencapai Tujuan Pembelajaran. Yogyakarta: Gava Media.

Emzir. (2012). Metodologi Penelitian Pendidikan: Kuantitatif dan Kualitatif. Jakarta: Rajawali Pers. 
Maryam, E., \& Fahrudin, A. (2020). Pengembangan Sound Card Laptop sebagai Alat Praktikum Fisika untuk Penentuan Percepatan Gravitasi Bumi. Silampari Jurnal Pendidikan Ilmu Fisika, 2(1), 29-40.

Mulyatingsih, E. (2014). Metode Penelitian Terapan Bidang Pendidikan. Bandung: Alfabeta.

Nugroho, K, G. \& Suyono. (2012). Optimalisasi Microsoft Office Power Point 2010 Dalam Pembuatan Media Interaktif Penggandaan Dokumen Untuk Program Keahlian Administrasi Perkantoran Sekolah Menengah Kejuruan Negeri 1. Jurnal Speed Sentra Penelitian Engineering dan Edukasi, 4(2), 29-37.

Prastowo, A. (2014). Pengembangan Bahan Ajar Tematik: Tinjauan Teoritis dan Praktis. Jakarta: Kencana.

Purwanto, dkk. (2016). Pelatihan Pengembangan Media Pembelajaran Interaktif Berbasis Microsoft Power Point Untuk Meningkatkan Kompetensi Guru Matematika di MGMP Kecamatan Pulogadung. Jurnal Sarwahita, 12(1), 26-31.

Sugiyono. (2007). Metode Penelitian Kuantitatif, Kualitatif dan R\&D. Bandung: Alfabeta.

Sugiyono. (2010). Metode Penelitian Pendidikan: Pendekatan Kuantitatif, Kualitatif dan $R \& D$. Bandung: Alfabeta.

Tanjung, M, R, dkk. (2018). Penerapan Model Problem Based Learning Berbantuan Simulasi Komputer Untuk Meningkatkan Keterampilan Pemecahan Masalah Siswa. Jurnal Inpafi, 6(3), 10-18.

Uskarina, M. (2019). TINJAUAN PELAKSANAAN PEMBELAJARAN REMEDIAL PADA MATA PELAJARAN FISIKA KELAS VIII SMP XAVERIUS LUBUKLINGGAU. SILAMPARI JURNAL PENDIDIKAN ILMU FISIKA, 1(2), 94101.

Zakiya, Z., Amin, A., \& Lovisia, E. (2019). PENERAPAN METODE EKSPERIMEN PADA PEMBELAJARAN FISIKA SISWA KELAS X SMAN 3 LUBUKLINGGAU TAHUN PELAJARAN 2018/2019. SILAMPARI JURNAL PENDIDIKAN ILMU FISIKA, 1(2), 130-138. 